\title{
Human cytomegalovirus DNA in cerebrospinal fluid
}

Jun Kohyama, Michiko Kajiwara, Masayuki Shimohira, Yoshihide Iwakawa, Hiroji Okawa

Department of

Paediatrics, Faculty of

Medicine, Tokyo

Medical and Dental

University, Japan

J Kohyama

M Kajiwara

M Shimohira

Y Iwakawa

H Okawa

Dr Jun Kohyama,

Department of Paediatrics,

Faculty of Medicine, Tokyo

Medical and Dental

Bunkyoh-ku, Tokyo 113,

Japan.

Accepted 15 June 1994
Correspondence to

University, Yushima 1-5-45,

\begin{abstract}
To determine the involvement of human cytomegalovirus (CMV) in conditions of neurological impairment, detection of CMV DNA was attempted in cerebrospinal fluid obtained from 45 neurologically affected children aged from 1 month to 17 years by means of the polymerase chain reaction. Four patients (congenital CMV encephalopathy with West's syndrome, acute encephalitis, chronic epileptic encephalopathy, and lissencephaly) had CMV DNA in their cerebrospinal fluid. CMV DNA was absent in the cerebrospinal fluid of 11 neurologically unaffected controls aged from 1 month to 11 years. Three patients with acute CMV hepatitis had no CMV DNA in their cerebrospinal fluid. Among the four patients who had CMV DNA in their cerebrospinal fluid, two did not excrete CMV DNA or CMV antigen in the urine. The possible pathogenetic significance of CMV DNA in the cerebrospinal fluid is discussed. By applying the
\end{abstract}

polymerase chain reaction to cerebrospinal fluid, the mode of brain invasion by CMV can be clarified further.

(Arch Dis Child 1994; 71: 414-418)

Though the involvement of human cytomegalovirus (CMV) in various conditions of neurological impairment is suggested, conventional clinical diagnostic methods, such as virus isolation and demonstration of an increase in a specific antibody in the serum or cerebrospinal fluid, have not always succeeded in clarifying the direct relationship between CMV and each condition. Recently, the polymerase chain reaction, applied to cerebrospinal fluid, has been established as a rapid and accurate means of exploring the role of human CMV in the central nervous system of not only HIV infected patients ${ }^{1-6}$ but also non-HIV infected patients. ${ }^{7-10}$ In this study, we applied the polymerase chain reaction to the cerebrospinal fluid of patients with various neurological impairments and neurologically unaffected controls, who seemed to be free from HIV infection.

Table 1 Details of neurologically affected patients with no human CMV DNA in their cerebrospinal fluid

\begin{tabular}{|c|c|c|c|c|}
\hline $\begin{array}{l}\text { Patient } \\
\text { No }\end{array}$ & $\begin{array}{l}\text { Age } \\
\text { (years) }\end{array}$ & Sex & Diagnosis & Urine \\
\hline P1 & $0 \cdot 3$ & $\mathbf{F}$ & West's syndrome & - \\
\hline P2 & $0 \cdot 3$ & $\mathbf{M}$ & West's syndrome & + \\
\hline P3 & 0.5 & $\mathbf{M}$ & West's syndrome & - \\
\hline P4 & 0.9 & $\mathbf{M}$ & West's syndrome & - \\
\hline P5 & $12 \cdot 0$ & $\mathbf{M}$ & Sequelae of West's syndrome & ND \\
\hline P6 & 0.4 & $\mathbf{M}$ & West's syndrome, lissencephaly & ND \\
\hline P7 & $5 \cdot 0$ & $\mathbf{F}$ & Hemimegalencephaly & ND \\
\hline P8 & $0 \cdot 2$ & $\mathbf{M}$ & CMV hepatitis, psychomotor delay & - \\
\hline P9 & 0.5 & $\mathbf{M}$ & CMV hepatitis, hypotonia & ND \\
\hline P10 & $0 \cdot 1$ & $\mathbf{F}$ & Convulsion, increase of IgM & - \\
\hline P11 & $0 \cdot 1$ & $\mathbf{M}$ & Microcephalus & + \\
\hline P12 & $0 \cdot 1$ & $\mathbf{F}$ & Epilepsy & ND \\
\hline P13 & $0 \cdot 2$ & $\mathbf{F}$ & Sequelae of herpes encephalitis & ND \\
\hline P14 & $0 \cdot 2$ & $\mathbf{M}$ & Liver dysfunction, psychomotor delay & ND \\
\hline P15 & $0 \cdot 2$ & $\mathbf{M}$ & Jaundice, hypotonia & - \\
\hline P16 & $0 \cdot 2$ & $\mathbf{F}$ & Epilepsy & ND \\
\hline P17 & $0 \cdot 3$ & $\mathbf{M}$ & Psychomotor delay & - \\
\hline P18 & 0.5 & $\mathbf{M}$ & Sotos's syndrome & - \\
\hline P19 & 0.5 & $\mathbf{F}$ & Congenital Leber's amaurosis & - \\
\hline P20 & 0.5 & $\mathbf{M}$ & Psychomotor delay & ND \\
\hline P21 & 0.5 & $\mathbf{M}$ & Psychomotor delay, liver dysfunction & + \\
\hline P22 & $0 \cdot 8$ & $\mathbf{M}$ & Epilepsy & ND \\
\hline P23 & $1 \cdot 0$ & $\mathbf{F}$ & Psychomotor delay & ND \\
\hline P24 & $1 \cdot 0$ & $\mathbf{M}$ & Sequelae of neonatal cold injury & + \\
\hline P25 & $1 \cdot 0$ & $\mathrm{~F}$ & Aseptic encephalitis & - \\
\hline P26 & $1 \cdot 0$ & $\mathbf{F}$ & Hydrocephalus & - \\
\hline P27 & $2 \cdot 0$ & $\mathbf{M}$ & Infantile neuroaxonal dystrophy & ND \\
\hline P28 & $3 \cdot 0$ & $\mathbf{F}$ & Mental retardation of unknown origin & ND \\
\hline P29 & $3 \cdot 0$ & $\mathbf{M}$ & Epilepsy & ND \\
\hline P30 & $4 \cdot 0$ & $\mathbf{M}$ & Aseptic encephalitis & ND \\
\hline P31 & $5 \cdot 0$ & $\mathbf{F}$ & Sequelae of neonatal asphyxia & ND \\
\hline P32 & $6 \cdot 0$ & $\mathbf{M}$ & Sequelae of neonatal hypoglycemia & ND \\
\hline P33 & $7 \cdot 0$ & $\mathbf{M}$ & Autism & - \\
\hline P34 & $8 \cdot 0$ & $\mathbf{F}$ & Epilepsy & ND \\
\hline P35 & $9 \cdot 0$ & $\mathbf{F}$ & Epilepsy & + \\
\hline P36 & $9 \cdot 0$ & $\mathbf{M}$ & Epilepsy & + \\
\hline P37 & $10 \cdot 0$ & $\mathbf{F}$ & Recurrent aseptic meningitis & - \\
\hline P38 & $10 \cdot 0$ & $\mathbf{M}$ & Migraine & ND \\
\hline P39 & $10 \cdot 0$ & $\mathbf{M}$ & Epilepsy, mental retardation & ND \\
\hline P40 & $11 \cdot 0$ & $\mathbf{F}$ & Abducent nerve palsy & ND \\
\hline P41 & $17 \cdot 0$ & $\mathbf{M}$ & Epilepsy, mental retardation & ND \\
\hline
\end{tabular}

CMV DNA on polymerase chain reaction: + (positive), - (negative), ND=not done.

\section{Patients and methods}

Cerebrospinal fluid samples were obtained from 45 patients with various neurological impairments; their details are shown in tables 1 and 2 . Another 11 samples obtained from neurologically unaffected patients $(\mathrm{C} 1$ to $\mathrm{C} 11)$ served as controls (table 3 ). Of these 11 control samples, six were obtained from patients with malignancies who had to be given intrathecal drugs to prevent invasion of the malignant cells into the central nervous system (C1-C6). Among the 45 neurologically impaired patients, one had been diagnosed as suffering from congenital CMV encephalopathy (P42), and another had CMV retinitis associated with Wiskott-Aldrich syndrome (P43). Of the other 43 patients, six were diagnosed as having West's syndrome (P1-P6). P42 also had West's syndrome. There were three patients with neuronal migration disorders: lissencephaly (P45 and P6), and hemimegalencephaly (P7). The diagnosis of acute CMV hepatitis (C11, P8, and P9) was based on liver dysfunction with increase of a specific IgM titre for CMV.

Informed consent was obtained from all the subjects or their parents. Thirty urine samples were examined for CMV DNA by the procedure reported elsewhere. ${ }^{11}$ We also applied this method to investigation of
POLYMERASE CHAIN REACTION PROCEDURES 
Table 2 Details of patients with human CMV DNA in their cerebrospinal fluid

\begin{tabular}{|c|c|c|c|c|c|}
\hline $\begin{array}{l}\text { Patient } \\
\text { No }\end{array}$ & $\begin{array}{l}\text { Age } \\
\text { (years) }\end{array}$ & Sex & Diagnosis & $\begin{array}{l}\text { Cerebrospinal } \\
\text { fluid }\end{array}$ & Urine \\
\hline P42 & $4 \cdot 2$ & $\mathrm{~F}$ & $\begin{array}{l}\text { Congenital CMV encephalopathy, West's } \\
\text { syndrome }\end{array}$ & + & + \\
\hline $\begin{array}{l}\text { P43 } \\
\text { P44 } \\
\text { P45 }\end{array}$ & $\begin{array}{r}4 \cdot 6 \\
9 \cdot 0 \\
17 \cdot 4\end{array}$ & $\begin{array}{l}\mathbf{M} \\
\mathbf{M} \\
\mathbf{M}\end{array}$ & $\begin{array}{l}\text { Acute encephalitis, Wiskott-Aldrich syndrome } \\
\text { Chronic epileptic encephalopathy } \\
\text { Lissencephaly }\end{array}$ & $\begin{array}{l}+ \\
+ \\
+\end{array}$ & $\begin{array}{l}+^{\star} \\
\mathrm{ND}\end{array}$ \\
\hline
\end{tabular}

CMV DNA on polymerase chain reaction: + (positive), - (negative), ND=not done.

$\star$ CMV antigen was not detected in urine with the shell vial culture method at the time when CMV DNA was detected in cerebrospinal fluid on the polymerase chain reaction.

cerebrospinal fluid samples. Aliquots of $50 \mu \mathrm{l}$ of cerebrospinal fluid, which had been taken carefully to avoid blood contamination and preserved at under $-80^{\circ} \mathrm{C}$ until treatment, was used as a template for the polymerase chain reaction.

Before DNA extraction samples were thawed and then centrifuged slowly to remove cellular components and other sediment; the supernatant was then used. To extract DNA, the procedure involving either glass power ${ }^{12}$ or polyethylene glycol ${ }^{13}$ was employed.

A pair of oligonucleotide primers kindly provided by Iatron Laboratories (Chiba, Japan) was used. These primers (MIE primers) were selected from the CMV major immediate early gene exon 4 sequence, and the expected length of the amplified DNA product was 426 base pairs. ${ }^{12}$

The reaction mixture for the polymerase chain reaction consisted of $10 \mathrm{mmol} / \mathrm{l}$ Trishydrochloric acid ( $\mathrm{pH} 8.3$ ), $50 \mathrm{mmol} / \mathrm{l}$ potassium chloride, $1.5 \mathrm{mmol} / 1$ magnesium chloride, $200 \mu \mathrm{mol} / \mathrm{l}$ of each dNTP, 0.025 $\mathrm{U} / \mu \mathrm{l}$ of Taq polymerase (all the latter components were from a GeneAmp polymerase chain reaction reagent kit; Perkin Elmer Cetus), $1 \mu \mathrm{mol} / 1$ of each primer, and $10 \mu \mathrm{l}$ of a sample. To avoid cross contamination, the reaction mixture (without the sample) was prepared as a 'master mix', and divided into individual tubes. Cellular DNA was extracted from human CMV laboratory strain Towne infected cells as described previously and used as a positive control. ${ }^{14}$ All experiments simultaneously included positive and negative (no DNA sample) controls. Amplification (30 cycles) was performed with a program Temp Control System PC-700 (Astec Co). Each cycle comprised denaturation for one minute at $94^{\circ} \mathrm{C}$, annealing for two minutes at $60^{\circ} \mathrm{C}$, and primer extension for three minutes at $72^{\circ} \mathrm{C}$. This cycle was followed by seven minutes at $72^{\circ} \mathrm{C}$.

Table 3 Details of neurologically unaffected patients (control group)

\begin{tabular}{|c|c|c|c|c|c|}
\hline $\begin{array}{l}\text { Patient } \\
\text { No }\end{array}$ & $\begin{array}{l}\text { Age } \\
\text { (years) }\end{array}$ & Sex & Diagnosis & $\begin{array}{l}\text { Cerebrospinal } \\
\text { fluid }\end{array}$ & Urine \\
\hline $\mathrm{C} 1$ & $0 \cdot 1$ & $\mathbf{M}$ & Familiar erythrophagocytic lymphohistiocytosis & - & + \\
\hline $\mathrm{C} 2$ & $0 \cdot 3$ & $\mathbf{M}$ & Familiar erythrophagocytic lymphohistiocytosis & - & ND \\
\hline C3 & $3 \cdot 0$ & $\mathrm{~F}$ & Acute leukaemia & - & + \\
\hline C4 & $6 \cdot 0$ & $\mathbf{M}$ & Malignant lymphoma & - & + \\
\hline C5 & $7 \cdot 0$ & $\mathbf{F}$ & Acute leukaemia & - & + \\
\hline C6 & $11 \cdot 0$ & $\mathbf{F}$ & Acute leukaemia & - & + \\
\hline C7 & $0 \cdot 1$ & $\mathbf{M}$ & Pulmonary proteinosis & - & - \\
\hline $\mathrm{C} 8$ & $0 \cdot 4$ & $\mathbf{M}$ & Liver dysfunction, cleft lip & - & ND \\
\hline C9 & $1 \cdot 0$ & $\mathbf{M}$ & Wiskott-Aldrich syndrome & - & ND \\
\hline $\mathrm{C} 10$ & $3 \cdot 0$ & $\mathbf{M}$ & $\begin{array}{l}\text { A sibling of a patient with congenital CMV } \\
\text { infection }\end{array}$ & - & - \\
\hline C11 & 0.9 & $\mathbf{M}$ & CMV hepatitis & - & + \\
\hline
\end{tabular}

CMV DNA on polymerase chain reaction: + (positive), - (negative), ND=not done.
The reproducibility of the results was confirmed in each sample.

\section{Results}

CMV DNA was detected in the cerebrospinal fluid of four patients (table 2 and fig 1). The details of these patients are given in the following section. CMV DNA was not detected in any of the control samples (table 3). Three patients with acute CMV hepatitis (C11, P8, and P9) lacked CMV DNA in the cerebrospinal fluid (tables 1 and 3). Urinary secretion of CMV DNA was detected in six of eight control samples, and in eight of 22 neurologically affected patients' ones (tables 1 and 3).

\section{CASE REPORTS}

\section{P42}

She was the second child of healthy nonconsanguineous parents born at term after a normal pregnancy without any perinatal complications. She had suffered from intractable seizures from 3 weeks of age. Her head circumference at 6 weeks of age was $38 \mathrm{~cm}$. Because of the increase of a specific IgM to $\mathrm{CMV}$ in both the serum and cerebrospinal fluid, congenital CMV encephalopathy was diagnosed. Though serial brain images showed no obvious abnormality including calcification or hydrocephalus, her psychomotor development was delayed. She presented a series of flexor spasms at $1 \cdot 1$ years, and electroencephalography (EEG) showed modified hypsarrythmia. CMV DNA was detected in her cerebrospinal fluid at age $4 \cdot 2$ years. Although intrathecal interferon succeeded in eliminating CMV DNA from her cerebrospinal fluid, her seizures have not been controlled yet, in spite of various anticonvulsants.

\section{P43}

$\mathrm{He}$ was the first child of healthy nonconsanguineous parents born at term after a normal pregnancy without any perinatal complications. He was diagnosed as having Wiskott-Aldrich syndrome at 1.4 years. Bone marrow transplantation using a haploidentical donor with $\mathrm{T}$ cell elimination was performed at 3.7 years of age. To control chronic graft versus host disease, he underwent immunosuppressive treatment. CMV DNA was

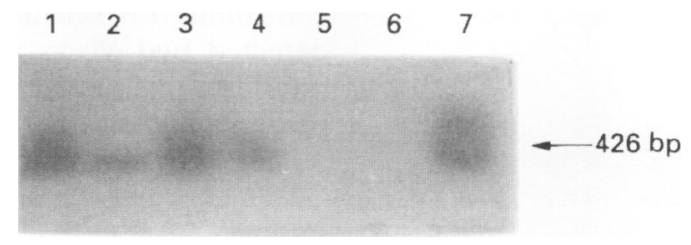

Figure 1 Southern hybridisation of polymerase chain reaction products. In all lanes, except for controls (lanes 6 and 7), the volume of the original cerebrospinal fluid (before precipitation) was $50 \mu \mathrm{l}$. Lanes 1 to 5 : polymerase chain reaction products resulting from amplication of cerebrospinal fluid specimens obtained from P42-P45 and C3, respectively; lane 6: negative control; lane 7: positive control (DNA extracted from a fibroblast infected with $C M V$ was used as the template); bp: base pair. 


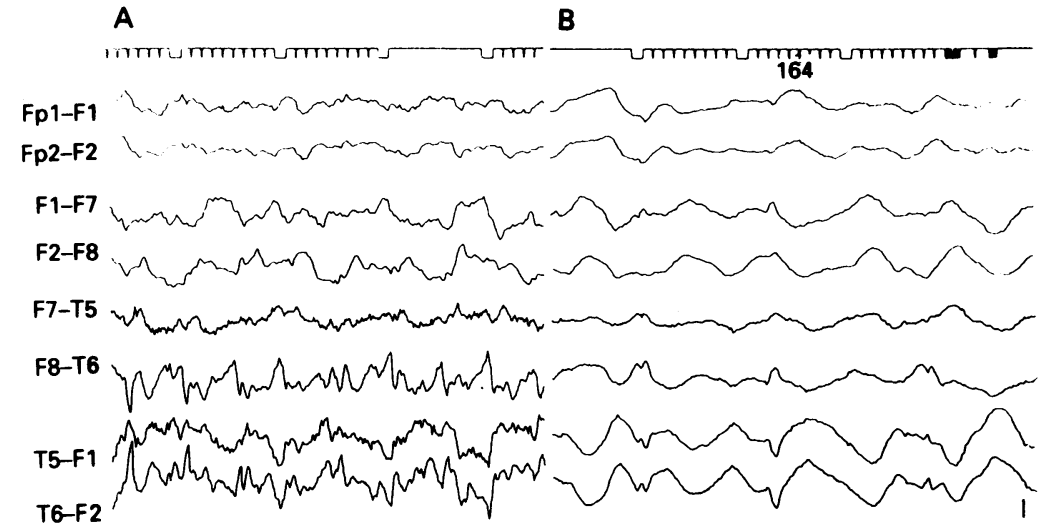

Figure 2 An example of the ictal EEG during left periorbital myoclonus $(A)$, and one of the interictal record $(B)$ of P43. Bursts of sharp waves $(A)$ and periodic slow waves with insertion of sharp waves (B) in the right temporal region can be noted (calibration $1 \mathrm{sec}$, $50 \mu v)$.
6 and 14 years of age. His psychomotor development was markedly delayed. At 17 years old, CMV DNA was detected in his cerebrospinal fluid. An antibody to CMV could be detected in his serum (ELISA IgG; $\mathrm{x} 4$ ), but not in his cerebrospinal fluid at that time. Magnetic resonance imaging of his brain revealed that he had lissencephaly.

\section{Discussion}

Application of the polymerase chain reaction to mononuclear cells in blood donors demonstrated that this method was more sensitive for detecting human CMV infection than serology. ${ }^{1718}$ The detection of CMV antigen and/or CMV DNA has been believed to be a true positive result despite a negative culture. ${ }^{19-21}$ The polymerase chain reaction was also shown to be a reliable means of diagnosing central nervous system infections due to herpesvirus including CMV. ${ }^{22}{ }^{23}$ The specificity of the polymerase chain reaction, applied to cerebrospinal fluid, in detecting CMV central nervous system involvement was established in patients infected by HIV. ${ }^{2-6}$ Also in immunocompetent hosts, CMV encephalitis was diagnosed on the basis of CMV DNA in cerebrospinal fluid detected on the polymerase chain reaction. 8

In the present study, human CMV DNA was not detected in the cerebrospinal fluid of the controls. Three patients with acute CMV hepatitis also had no CMV DNA in their cerebrospinal fluid. Invasion of CMV into the central nervous system must not always occur, even during the acute phase of CMV infection. Recently, the polymerase chain reaction revealed the persistence of genomic materials of herpes simplex virus within the human central nervous system even 17 years after acute encephalitis. ${ }^{24}$ The existence of CMV DNA in the cerebrospinal fluid of P42 indicated that the genomic material of CMV could persist in the central nervous system for at least four years. Detection of CMV DNA in the cerebrospinal fluid of P44 and P45 long after the probable CMV central nervous system invasion was possible.

Among the four patients presented, other than P42, none could be supposed to have CMV infection in the central nervous system according to the results obtained with conventional methods. Interestingly, P42 lacked typical features of congenital CMV infection. ${ }^{25}$ The time of central nervous system invasion and/or each host-agent interaction may modify the clinical picture. Moreover, she had West's syndrome. CMV has been known to be an agent inducing West's syndrome, ${ }^{26} 27$ and CMV DNA was detected in the CSF of a patient with West's syndrome on the polymerase chain reaction. ${ }^{7}$ Although there is an association between West's syndrome and CMV infection, ${ }^{27}$ six of the patients with West's syndrome (Pr-P6) in this study lacked CMV DNA in their cerebrospinal fluid.

CMV retinitis could be diagnosed from specific retinal findings in P43, however, it was not obvious whether or not CMV was the normal pregnancy without any perinatal complications. His parents noticed a delay in his psychomotor development at 9 months of age, and he was diagnosed as having cerebral palsy. $\mathrm{He}$ suffered from intractable seizures between 
agent causing his encephalitis. As the established procedures for diagnosing CMV infection were of little use in this patient, the polymerase chain reaction had quite a crucial role in his diagnosis. On postmortem examination we observed glial nodules in his mesencephalon. Discrete glial nodules with a predilection for grey matter structures are suggested to indicate the presence of CMV encephalitis regardless of whether or not clinical encephalopathy is identified. ${ }^{28}$ Moreover, in CMV encephalitis, significantly more nodules have been reported to occur in the basal ganglia, diencephalon, and brain stem than in the cortical white matter. ${ }^{28}$ These facts strongly support the fact that P43 had suffered from CMV encephalitis.

In P44 we supposed that an isolated CMV invasion of the central nervous system or the time of CMV infection of the central nervous system might have made him immunotolerant to CMV, and thus caused his illness. ${ }^{10}$ Recently, a case of congenital and chronic CMV encephalitis found at necropsy was reported. ${ }^{27}$ Similar patients should be studied and attention should be paid to their brain pathology.

Regarding P45, there have been six reported patients with lissencephaly who have had congenital CMV infection diagnosed by established methods. ${ }^{29}{ }^{30}$ In the present study, other patients with neuronal migration disorders (P6 and P7) had no CMV DNA in their cerebrospinal fluid. Suffice to say that P45 supports the possibility that disturbance of neuronal migration can be brought about by $\mathrm{CMV}$ central nervous system invasion. ${ }^{19}$

The ratio of positive CMV DNA in the urine of the controls $(6 / 8)$ was higher than that in neurologically affected patients (8/22). However, the wide prevalence of asymptomatic CMV infection in Japan is known, ${ }^{31}$ and CMV DNA in the urine is supposed to indicate the reactivation of CMV. ${ }^{11}$ The present results may reflect this wide prevalence, and may not mean a higher ratio of CMV infection in the controls than in the patients. Interestingly, we detected CMV DNA in the cerebrospinal fluid of patients who did not excrete CMV DNA (P44) or CMV antigen (P43) in their urine. The clinical significance of the detection of CMV DNA seems to be greater when CMV DNA is detected in the cerebrospinal fluid than in the urine.

We demonstrated that invasion of CMV into the central nervous system does not occur, even during the acute phase of CMV infection. Detection of CMV DNA in the cerebrospinal fluid hardly occurs in neurologically unaffected conditions. We have discussed the possible close association of CMV with each illness of patients who had CMV DNA in their cerebrospinal fluid. Though the time of central nervous system invasion remains to be determined in each of our patients, to prove the aetiological role of $\mathrm{CMV}$, the polymerase chain reaction must constitute a novel means of elucidating the pathogeneses in neurologically affected patients with an unknown origin based upon the results with conventional procedures.
By applying the polymerase chain reaction to the cerebrospinal fluid, the mode of invasion of CMV (or another virus) into the developing central nervous system can be clarified further. We conclude that the polymerase chain reaction is a new addition to the established techniques for diagnosing viral infections. ${ }^{32}$

We wish to thank Professor Junichi Yata for critically reading this manuscript.

1 Darnell RB. The polymerase chain reaction: application to nervous system disease. Ann Neurol 1993; 34: 513-23.

2 Cinque $\mathrm{P}$, Vago $\mathrm{L}$, Brytting $\mathrm{M}$, et al. Cytomegalovirus infection of the central nervous system in patient cerebrospinal fluid. $₹$ Infect Dis 1992; 166: 1408-11.

3 Wolf DG, Spector SA. Diagnosis of human cytomegalovirus central nervous system disease in AIDS patients by DNA amplification from cerebrospinal fluid. $\mathscr{f}$ Infect Dis 1992; 166: 1412-5.

4 Gozlan J, Salord JM, Roullet E, et al. Rapid detection of cytomegalovirus DNA in cerebrospinal fluid of AIDS patients with neurologic disorders. $\mathcal{F}$ Infect Dis 1992; 166: 1416-21.

5 Clifford DB, Buller RS, Mohammed S, Robison L, Storch GA. Use of polymerase chain reaction to demonstrate cytomegalovirus DNA in CSF of patients with human immunodeficiency virus infection. Neurology 1993; 43: 75-9.

6 Rolfs A. Rapid detection of cytomegalovirus structures in cerebrospinal fluid and brain biopsies by polymerase chain reaction. Acta Neurol Scand 1993; 88: 236-8.

7 Mashima K, Yamazaki T, Kuwahara K, et al. West syndrome and cytomegalovirus infection [in Japanese] Shouninaika 1991; 23: 1454-8.

8 Studahl M, Ricksten A, Sandberg T, Bergstrom T, Elowson $S$. Cytomegalovirus encephalitis in four immunocompetent patients. Lancet 1992; 340: 1045-6.

9 Numata K, Osada N, Wakai S, Tachi N, Chiba S. A case of myoclonic encephalopathy of infancy associated with cytomegalovirus infection [in Japanese]. No To Hattatsu 1993; 25: 569-71.

10 Kohyama J, Suzuki N, Kajiwara M, Shimohira M, Iwakawa $Y$. A case of chronic epileptic encephalopathy of neonatal Y. A case of chronic epileptic encephalopathy of neonatal onset - a probable concern
Brain Dev 1993; 15: 448-52.

11 Kajiwara M, Yamaguchi Y, Hirai K, Yata J. Increased urinary excretion rate of human cytomegalovirus in children with malignancy: detection by polymerase chain reaction. Acta Paediatr fpn 1993; 35: 387-93.

12 Yamaguchi Y, Hironaka T, Kajiwara M, Tateno E, Kita H, Hirai K. Increased sensitivity for detection of human cytomegalovirus in urine by removal of inhibitors for polymerase chain reaction. $f$ Virol Methods 1992; 37: 209-18.

13 Kimpton CP, Corbitt G, Morris DJ. Comparison of polyethylene glycol precipitation and ultracentrifugation for recovery of cytomegalovirus from urine prior to detection of DNA by dot-blot hybridization. 7 Virol Methods tion of DNA by

14 Hirai K, Watanabe Y. Induction of alpha-type DNA polymerase in human cytomegalovirus-infected WI-38 cells. Biochim Biophys Acta 1976; 447: 328-39.

15 Bloom JN, Palestine AG. The diagnosis of cytomegalovirus retinitis. Ann Intern Med 1988; 109: 963-9.

6 Price TA, Digioia RA, Simon GL. Ganciclovir treatment of cytomegalovirus ventriculitis in a patient infected with human immunodeficiency virus. Clin Infect Dis 1992; 15: 606-8.

17 Stanier P, Taylor DL, Kitchen $\mathrm{AD}$, Wales N, Tryhorn Y, Tyms AS. Persistence of cytomegalovirus in mononuclear cells in peripheral blood from blood donors. BMF 1989; cells in periphe $897-8$.

18 Bevan IS, Daw RA, Day PJR, Ala FA, Walker MR Polymerase chain reaction for detection of human cytomegalovirus in a blood donor population. $\mathrm{Br} \mathcal{J}$ Haematol 1991; 78: 94-9.

19 Drew WL. Diagnosis of cytomegalovirus infection. Rev Infect Dis 1988; 10 (suppl 3): S468-76.

20 Dunn DL, Najarian JS. New approaches to the diagnosis prevention, and treatment of cytomegalovirus infection after transplantation. Am $\mathcal{F}$ Surg 1991; 161: 250-5.

21 Einsele H, Ehninger G, Steidle M, et al. Polymerase chain reaction to evaluate antiviral therapy for cytomegalovirus disease. Lancet 1991; 338: 1170-2.

22 Aslanzadeh J, Osmon DR, Wilhelm MP, Espy MJ, Smith TF. A prospective study of the polymerase chain reaction for detection of herpes simplex virus in cerebrospinal fluid submitted to the clinical virology laboratory. Mol Cell Probes 1992; 6: 367-73.

23 Rozenberg F, Lebon P. Amplification and characterization of herpesvirus DNA in cerebrospinal fluid from patients of herpesvirus DNA in cerebrospinal fluid from patients

24 Nicoll JAR, Love S, Kinrade E. Distribution of herpes virus DNA in the brains of human long-term survivors of encephalitis. Neurosci Lett 1993; 157: 215-8.

25 Hanshaw JB. Cytomegalovirus infections. Pediatr Rev 1981 2: $245-51$ 
26 Appleton RE. Infantile spasms. Arch Dis Child 1993; 69: $614-8$.

27 Riikonen R. Infantile spasms: infectious disorders. Neuropediatrics 1993; 24: 274-80.

28 Morgello S, Cho ES, Nielsen S, Devinsky O, Petito CK Cytomegalovirus encephalitis in patients with acquired Cytomegalicus en syndrome: an autopsy study of 30 ve 289-97. Norman MG, Roberts M, Sirois J, Tremblay LJM.
Lissencephaly. Can $\mathcal{F}$ Neurol Sci 1976; 3: 39-46.
30 Hayward JC, Titelbaum DS, Clancy RR, Zimmerman RA. Lissencephaly-pachygyria associated with congenita cytomegalovirus infection. I Child Neurol 1991; 6: 109-14.

31 Numazaki $\mathrm{Y}$, Yano $\mathrm{N}$, Morizuka $\mathrm{T}$, Takai S, Ishida $\mathrm{N}$. Primary infection with human cytomegalovirus: virus isolation from healthy infants and pregnant women. $A m \mathcal{F}$ Epidemiol 1970; 91: 410-7.

32 Smith TF, Wold AD, Espy MJ, Marshall WF. New developments in the diagnosis of viral infection. Infect Dis Clin North Am 1993; 7: 183-201. 